\title{
Ideologi: Faktor Konflik dan Kegagalan Timur Tengah
}

\author{
Muhammad Zainal Muttaqin \\ Pascasarjana Ilmu Hubungan Internasional, Universitas Indonesia \\ Email: zeyneilzuqin@gmail.com \\ Diserahkan: 06 September 2018 | Diterima: 26 November 2018
}

\begin{abstract}
The following article explains how Western ideologies become major factor of conflicts and failures in the Middle East. In this paper the author looks from the perspective of ideological hegemony. Ideology undermines the political and economic systems that cause social inequality and accelerate the outbreak of conflict in the Middle East. The author raised Syria and Libya as examples to prove the factors that led to the conflict. The author argues that the main cause of the Middle East conflict is the influence of Western ideology that cannot be accepted by government in power or even the people, so that it triggers conflicts and even war. Democracy which is an accepted model in various countries cannot be applied in the Middle East. The author also criticized the failure of democracy implementation and liberal economies in the Middle East.
\end{abstract}

Keywords: Ideology, Modernism, Imperialism, Capitalism, Democracy, Middle East.

\begin{abstract}
Abstrak
Tulisan berikut menjelaskan bagaimana ideologi Barat menjadi faktor utama terjadinya konflik dan kegagalan negara di Timur Tengah. Dalam tulisan ini penulis melihat dari perspektif hegemoni ideologi. Ideologi merusak sistem politik dan ekonomi yang menyebabkan kesenjangan sosial sehingga mempercepat pecahnya konflik di Timur Tengah. Penulis mengangkat Suriah dan Libya sebagai contoh untuk membuktikan faktor yang mendorong terjadinya konflik. Penulis berargumen bahwa penyebab utama dari konflik Timur Tengah adanya pengaruh ideologi Barat yang belum bisa diterima baik oleh pemegang kekuasaan maupun masyarakatnya sehingga memicu perpecahan dan bahkan peperangan. Demokrasi merupakan model yang diterima di berbagai negara tidak bisa diterapkan di Timur Tengah. Penulis juga memberikan kritikan pada kegagalan implementasi demokrasi dan ekonomi liberal di Timur Tengah.
\end{abstract}

Kata Kunci: Ideologi, Modernisme, Imperialisme, Kapitalisme, Demokrasi, Timur Tengah.

\section{PENDAHULUAN}

Di tengah berbagai kemajuan secara global, konflik dan peperangan tanpa henti menjadi agenda diberbagai pelosok dunia, terutama di Timur Tengah yang telah menjadi tanah sengketa bagi berbagai peradaban untuk kesekian abad. Timur Tengah yang mewarisi berbagai suku bangsa, agama dan budaya kerap bagaikan campuran adonan yang tak pernah rampung untuk dimasak. Ditambah lagi dengan tatanan politik di setiap wilayah yang meyerupai Firaun di masa lampau. Kekuasaan menggoda setiap penguasa akan kemewahan yang diperoleh dari hasil sumberdaya minyak bumi. Sehingga menjadikan Timur Tengah yang kaya akan sumber minyak bumi ini menjadi tempat pertumpahan darah semenjak 
peradaban manusia lahir. Sebagai faktanya sekarang Timur Tengah dikontruksikan dengan konflik, fanatisme Islam dan bahkan terorisme. Di sisi lain Timur Tengah juga diagungkan sebagai tempat kelahiran berbagai peradaban dengan kekayaan kultur budaya, sumberdaya alam, hingga pusat kemewahan dan kehidupan yang serba mahal mempesona.

Timur Tengah yang telah menjadi kawasan konflik untuk kesekian abadnya sangat sulit untuk kembali menjadi sebuah "Timur Tengah" yang diimpikan oleh masyarakat dunia. Perbedaan suku etnik, agama hingga kesenjangan sosial ekonomi menjadikan wilayah ini menjadi sebuah kawasan yang rentan terjadinya konflik antar agama dan etnik hingga perebutan kekuasaan antara grup etnis tertentu. Belum lagi ditambah oleh unsur kekayaan alam seperti minyak bumi yang menjadi faktor utama dalam perpecahan negara. Ideologi yang ditinggalkan barat pada masa mandat Perancis dan Inggris di wilayah ini hanya sampai pada mendirikan negara yang bersifat otokratik, yang sebagaian besarnya dikuasai oleh sebagian kecil keluarga bawaan dari kolonialisme. Sehingga ideology barat terutama "demokrasi" menjadi senjata utama dalam meruntuhkan rejim yang tidak diinginkan oleh sistem kapitalisme global.
Pada dasarnya perselisihan ideology hanyalah terjadi antara ideologi kapitalisme dengan rejimyang tidak mendukung kapitalisme global. Seperti rejim sosialis dan komunisme. Timur Tengah terus mengalami konflik selama ideologi hegemon menjadi rujukan dalam politik bernegara. Di mana ideologi-ideologi barat menjadi motivasi politik yang dibungkus dengan unsur demokrasi, Islam, dan bahkan nasionalime-etnik. Berbagai unsur politik digunakan sebagai sentimen untuk membangun indentitas sebuah bangsa dalam bernegara. Unsur tersebut sebenarnya pemecah yang menimbulkan peperangan dengan suku etnis dan pemeluk agama yang berbeda. Penulis berargumen bahwa Timur Tengah tidak akan pernah stabil dikarenakan ideologi barat seperti rejim demokrasi yang berkembang di wilayah ini tidak sesuai dengan latar belakang masyarakatnya. Baik dari segi nilai agama, kultur dan budaya hingga sistem politik. Konflik yang terjadi di Timur Tengah menjadi tanggung jawab komunitas internasional dan harus memberikan solusi yang kongkrit. Karena sudah saatnya masyarakat Timur Tengah menerima kesejahteraan dan masa depannya.

Penulis melihat fenomena konflik yang terjadi di Timur Tengah dari perspektif teori kritikal Gramsci. Ideologi yang berkembang merupakan 
pemikiran yang mendominasi kekuasaan dan hanya mewakili kepentingan sebagian golongan semata. Sehingga ideologi seperti demokrasi, liberalisme dan kapitalisme merupakan gagasan yang hanya memberikan kepentingan ekonomi bagi golongan tertentu. Sebagai contoh idiologi "demokrasi" yang digunakan kelompok penguasa kapitalis barat untuk menumbangkan pemerintahan Libya Kaddafi demi kemenangan ideologi kapitalis dan juga kepentingan sumber daya alam. Oleh karena itu segala aspek dalam kehidupan dibentuk bedasarkan kepentingan sebagian golongan kelompok. Hal ini menjadikan kultur ideologi hegemon menguasai golongan tertentu.

\section{Modernisasi Barat dan Timur Tengah}

Modernisme merupakan sebuah fenomena yang berkembang di Eropa hingga lahirnya renaissance (enligbtenment). Fenomena ini merupakan revolusi pemikiran yang mendorong manusia untuk berpikir secara bebas dan moderen. Sehingga melahirkan kelas borjuis/bangsawan yang memiliki pemikiran untuk mendirikan modern-state yang sangat berbeda dengan sistem kekuasaan monarki sebelumnya. Perkembangan peradaban di Eropa melahirkan merkantilisme dan kapitalisme yang mendorong kaum borjuis Eropauntuk menjadi kolonial raksasa dalam memenuhi kebutuhan dan merenggut kapital lebih besar hingga pecahnya perang dunia I dan II.

Meningkatnya berbagai kebutuhan yang disebabkan oleh Revolusi Industri Inggis, mendorong penjelajah laut untuk mendapatkan bahan baku hingga ke pelosok dunia. Kebutuhan bahan baku dan perkembangan industri yang terjadi selama beberapa abad di Eropa baik secara ekonomi maupun ideologi telah merubah bangsa Eropa dalam berpikir, baik gaya hidup hingga politik yang melahirkan nasionalisme dan praktek demokrasi liberal. Akan tetapi apakah semua hal yang sama telah terjadi di “Timur Tengah"?.

Wilayah yang kerap dikenal Timur Tengah, tidak pernah mengalami enlightenment seperti layaknya yang terjadi di Eropa ataupun revolusi industri yang terjadi di Inggris. Wilayah yang dulunya berada di bawah kekuasaan Turki Usmani hingga Perang Dunia I ini hanyalah tempat di mana peradaban kuno lahir yang silih berganti. Akan tetapi setelah pewaris terakhir Muawiyah tersapu habis oleh Imperium Turki Usmani, menjadikan wilayah ini tempat persinggahan bagi pedagang Lavantine yang berasal dari Suriah, Lebanon, Israel dan Jordan (Shea, 2003). Setelah Turki Usmani hilang kekuasaan di wilayah ini pada abad ke 19, menjadikan wilayah ini 
sebagai lahan baru bagi kolonialisme Eropa. Inggris dan Perancis secara mutlak setelah Perang Dunia I menjadikan wilayah ini sebagai wilayah kekuasaan. Kemudian setelah berahirnya Perang Dunia II diwariskan kepada keluarga ekskolonialisme untuk menjadi penguasa di wilayah ini.

Dari segi sejarah Timur Tengah sangatlah berbeda jika dibandingkan dengan Eropa. Eropa yang mengalami kemajuan baik dalam sistem ekonomi maupun politik, wilayah ini hanyalah menjadi bagian yang berada di bawah kekuasaan Imperium dan kolonialisme. Oleh sebab itu wilayah ini tidak pernah menjadi pusat kemajuan akan tetapi Timur Tengah hanya menjadi bagian "pinggiran" (peripheral). Timur Tengah berkembang secara tradisional dengan kekayaan kultur dan ideologi tersendiri. Tempat lahirnya beragam agama dan ultur yang berakar pada nilai nilai keagamaan. Sehingga perkembangan yang terjadi di Timur Tengah sangatlah berlawanan dengan apa yang berkembang di Eropa. Ideologi yang berkembang di Eropa berbeda dengan apa yang berkembang di Timur Tengah. Timur Tengah yang dipenuhi oleh beragam suku dan ras serta kultur yang sangat kental menjadikan wilayah ini seperti minyak dan air yang tidak pernah bisa disatukan. Sehingga ideologi barat terutama rejim demokrasi menjadi ancaman bagi kekuasaan otokratik (kekuasaan sebuah keluarga) yang diwariskan secara turun-temurun.

\section{Ideologisasi Istilah "Timur Tengah"}

"Timur Tengah" (Midlle East) merupakan sebutan untuk wilayah Timur dari Barat (Eropa) bagi kolonial barat semenjak runtuhnya kekuasan Turki Usmani di abad kesembilan belas. Timur Tengah tidak pernah menjadi sebuah terminologi yang menjelaskan letak geografis dengan tepat. Karena Timur Tengah bukanlah wilayah bisa ditandai secara fisik. Penyebutan Timur Tengah merupakan sebutan negara barat yang memposisikan geografisnya sebagai central/pusat dunia. Setelah Perang Dunia I "Timur Tengah" merupakan sebutan kolonialisme Eropa ke wilayah Timur Imperial Turki Usmani. Dalam beragam literatur kajian Timur'Tengah kerap ditemukan kata "Oriental" atau kajian yang mempelajari wilayah Timur Tengah. Wilayah ini meliputi wilayah Sahara Afrika, Mesir, perbatasan India hingga ke Teluk Bosphorus Istanbul. Dalam literatur, penggunaan Timur Tengah pertama kali digunakan oleh geopolitikus Amerika Alfred Thayer Mahan pada tahun 1902 (Koppes, 1976). Penyebutan Timur Tengah menjadi terminologi asing yang diberikan oleh barat. Secara ideologis Timur Tengah adalah sebuah wilayah yang dibentuk berdasarkan pandangan 
dan kepentingan barat dalam melakukan penjajahan pada abad 19 hingga sekarang (Gerald \& Alasdair, 1985).

\section{Komposisi Etnik Yang Heterogen dan Ideologi Agama Yang Kental}

Timur Tengah merupakan rumah bagi puluhan etnisitas dan suku agama. Bangsa Arab merupakan suku mayoritas yang ada di Timur Tengah (Ethnic groups in the Middle East, 2018). Selain itu di antaranya juga terdapap suku etnik Iran, Turkmen, Urdu, Kurdi, Yahudi, Azeri, Pasytun dan Berber (Shoup, 2011). Sehingga komposisi penduduk di setiap negara di Timur Tengah pun sangatlah beragam. Mesir merupakan negara yang memiliki populasi penduduk Arab Sunni paling banyak di Timur Tengah dan Bahrain merupakan negara yang memiliki populasi paling rendah di dalam regional (Demographics of Egypt, 2018).

Timur Tengah juga tempat lahirnya nenek moyang dari berbagai agama. Geografis ini dimayoritaskan oleh penduduk Muslim. Akan tetapi Timur Tengah juga terdapat pemeluk agama Kristen, dan Yudaism, Yedisims, Zerdus, Nusairi, Namiri, dan bahkan Ensari (Religion in the Middle East, 2018).

Mayoritas populasi Timur Tengah adalah suku Arab, suku Arab pun secara agama terpecah ke dalam dua golongan yaitu Sunni dan Syiah. Oleh sebab itu nilai agama juga menjadi salah satu pemicu terjadinya konflik antar suku yang tak kunjung selesai hingga turun-temurun. Komposisi penduduk yang heterogen ini merupakan salah satu faktor konflik antara grup etnik dalam memperebutkan kekuasaan politik. Perbedaan nilai agama yang berbeda juga merupakan faktor konflik dalam kompetisi kekuasaan. Sehingga nilai demokrasi barat yang berakar pada sekularisme, kebebasan sangat sulit untuk direalisasikan, apalagi membawa demokrasi yang berbau liberal yang mengancam kekusaan otokratik atau kekuasaan keluarga. Seperti contohnya keluarga Esad di Suriah yang merupakan penganut agama minoritas Nusairi. Memimpin penduduk yang 90\% manyoritas Sunni (Akdemir, 2000). Sehingga menimbulkan pemerintahan yang otokratik dan memicu konflik antar suku etnik dan agama. Tidaklah heran ketika sebagian besar masyarakat Suriah menolak pemimpinnya sendiri karena menganggap penindasan dari keluarga yang beragama Nusairi terhadapat penduduk Sunni selama puluhan tahun.

Contoh lain dari perpecahan yang disebabkan oleh perbedaan suku agama dan etnis Irak, di mana partai politik menyimbolkan nilai agama dan merepresentasikan suku tertentu. 
Partai politik di Irak hanya dipenuhi oleh masyarakat Sunni atau Syiah. Sehingga melahirkan partai politik yang hanya dikomposisikan oleh suku Turkmen, Arab atau Kurdi. Sehingga bisa disimpulkan bahwa komposisi penduduk yang sangat heterogen dan bervariasi memberikan peluang bagi setiap suku agama atau etnik di Timur Tengah untuk memiliki pandangan yang khas dan memiliki pendekatan berbeda terhadap ideologi barat.

\section{Kepemerintahan Otokratik dan Monarki}

Timur Tengah yang merupakan wilayah peninggalan kolonialisme memiliki sistem politik yang sangat unik. Setelah kepemerintahan mandat Inggris, Prancis dan Rusia berakhir di wilayah ini pada abad ke 19, bagianbagian negara di wilayah inidiwariskan kepada keluarga yang memiliki hubungan dekat dengan negara mandat. Ini akan mempermudah bagi negara mandat dalam menjalin hubungan diplomatik di kemudian hari untuk berbagai kepentingan. Akan tetapi pemberian kekuasaan kepada keluarga tertentu di wilayah ini telah menyebabkan berkembangnya negara yang bersifat otokratik di bawah Partai Sosialis Arab Ba'ath (Arab Baas Socialist Party). Pemerintahan hanya dipegang oleh sebagian kecil anggota keluarga atau yang memiliki afiliasi dengan Partai Ba'ath (Atay, 2000).
Sistem etnik dan keluarga yang terdapat di Timur Tengah menyebabkan kekuasaan politik dikuasai oleh keluarga tertentu. Sehingga tatanan politik di Timur Tengah cenderung bersifat Monarki dan dikuasai oleh satu keluarga secara turun-temurun. Seperti Saudi Arabia, Qatar, Uni Emirat Arab dan Kesultanan Yaman. Tidak hanya itu, juga terdapat sistem politik yang bersifat republik dan berbasis militer seperti Mesir dan Iraq. Akan tetapi masih tetap saja meneruskan kekuasaan warisan yang hanya mengedepankan kepentingan kelompok tertentu dan juga menjaga kekuasaan yang diperoleh. Sehingga walaupun ada sistem yang demokratis, dalam prakteknya hanya terdapat rejim berbasis militer dan radikal yang dikuasai oleh keluarga tertentu (Lenczowski, 1988).

Dengan adanya hasrat dan keinginan untuk berkuasa, hampir di setiap etnik di Timur Tengah sulit untuk menerima demokrasi. Nilai demokrasi sendiri bahkan ditolak oleh otoritas yang berkuasa dan bahkan kawasan ini menolak kehadiran demokrasi (Ottaway \& Carithers, 2004). Dikarenakan kekuasaan ditafsirkan sebagai milik keluarga berdarah biru. Oleh sebab itu, ideologi kekuasaan yang ada di Timur Tengah sangatlah berlawanan dengan ideologi barat. Sehingga ideologi barat seperti 
modernisme, nasionalisme, bahkan demokrasi pun tidak mungkin berkembang di Timur Tengah. Oleh sebab itu demokratisasi Timur Tengah hanyalah agenda bagi negara barat yang memicu konflik dalam memperebutkan kekuasaan.

\section{Kegagalan Ekonomi Liberal dan Realisme}

Dari total 17 negara (Arab Saudi, Bahrain, Irak, Iran, Israel, Kuwait, Lebanon, Mesir, Palestina, Oman, Qatar, Siprus, Suriah, Turki, Uni Emirat Arab, Yaman dan Yordania) yang ada di wilayah Timur Tengah, tidak semua negara adalah penghasil minyak bumi. Terdapat juga negara yang tidak memiliki sumber daya alam minyak ataupun gas. Seperti Israel yang bergantung pada export teknologi yang dikembangkannya. Contoh lain adalah Yordania yang terus berusaha menjadi pusat perdagangan agar bisa tetap bertahan di dalam perekonomian global. Secara umum negara di Timur Tengah tergantung pada satu sumber pendapatan yaitu minyak bumi. Ketergantungan pada satu komoditas seperti minyak bumi menyebabkan ekonomi yang tidak stabil akibat regulasi yang diciptakan oleh pasar komoditas global. Oleh karena itu ketika pendapatan utama menurun menimbulkan masalah ekonomi yang serius. Seperti halnya yang terjadi di
Mesir yang mangakibatkan pengangguran massal yang masif.

Paham ekonomi liberal yang dipahami negara di Timur Tengah sangatlah berbeda. Masyarakat Timur Tengah hanya paham akan kebebasan dalam bertransaksi dan dagang. Tidak menyadari bahwa negara-negara tersebut harus bersaing di berbagai produk dalam ekonomi global. Dengan mengandalkan satu komoditas saja sebagai roda ekonomi menyebabkan sektor lain tidak bisa berkembang. Negara di Timur Tengah menjadi tidak produktif dan hanya menjadi negara konsumtif atau pasar bagi negara lain. Dari sisi perekonomian Timur Tengah adalah wilayah yang dirugikan dan ketinggalan jauh untuk berkompetisi, ini juga diakibat oleh pemerintah yang hanya menggunakan sebagian besar pendapatan negarauntuk

pembelanjaan pertahanan seperti alutsista. Pengeluaran ini telah menguras sebagian besar pendapatan nasional hingga $4.2 \%$ dari GDP (Military Expenditure, 2017). Pendapatan tidak dialihkan untuk investasi yang memberikan kontribusi untuk pertumbuhan ekonomi. Hal seperti ini persis seperti yang dialami oleh pemerintah Mesir, Iran, Suriah dan Yaman.

Paham keharusan memiliki kekuatan militer yang kuat untuk menjaga rejimnya telah membuat 
pemerintah di Timur Tengah mengeluarkan anggaran besar-besaran untuk pertahanan. Pendapatan negara sebagian besarnya digunakan untuk pembelian senjata. Karena penguasa di Timur Tengah lebih mementingkan keamanan rejim dan kekuasaannya dibandingkan kesejahteraan rakyat. Oleh sebab itu investasi yang dilakukan untuk sektor lain sangatlah sedikit. Seperti tidak adanya pemberdayaan pangan, kurangnya infrastruktur air bersih, dan minimnya investasi di infrastruktur utama lainnya. Sehingga menjadikan Timur Tengah sebagai pasar untuk export pangan. Kesalahpahaman pemerintah akan pentingnya kekuatan militer dalam manjaga keseimbangan di Timur Tengah, telah menguras semua pendapatan negarauntuk

pembelanjaan yang akhirnya membawa ancaman bagi wilayah Timur Tengah. Seperti yang dilakukan oleh Saudi Arabia dengan pembelanjaan senjata hingga 70 milyar dolar di tahun 2017 (World Military Spending 2017). Hal ini membawa kekhawatiran ke kawasan terutama yang berpenduduk Syiah. Oleh sebab itu realisme telah menutup mata panguasa di Timur Tengah dengan mementingkan apa yang sebenarnya tidak memberikan kesejahteraan bagi rakyatnya, dan bahkan menguntungkan negara barat dari segi pembelanjaan negara. Penulis sendiri melihat ini adalah sebuah tipuan ideologi barat yang dilakukan terhadap Timur Tengah untuk keuntungan dari industri persenjataan tanpa memperdulikan apa masalah sebenarnya yang dihadapi Timur Tengah. Di mana Timur Tengah menjadi pasar bagi industri alutsista Barat. Hal ini merupakan kekejaman kapitalisme global yang hanya fokus pada keuntungan dengan menanamkan persepsi kenegaraan yang salah terhadap penguasa politik di Timur Tengah.

Investasi di sektor yang memacu ekonomi di negara-negara Timur Tengah sangatlah sedikit. Seperti kurangnya investasi di sektor pangan, kanalisasi, infrastruktur, industri dan bahkan pendidikan. Hal ini menimbulkan masalah baru yang sangat berpengaruh secara global. Masalah utama tersebut adalah urbanisasi yang tidak terkontrol yang disebabkan oleh peningkatan populasi. Ditambah lagi dengan infrastruktur yang tidak memadai seperti kanalisasi menjadikan kota tidak terawat dan kotor. Seperti apa yang terjadi di Kairo, Karachi dan bahkan Bagdad yang pernah menjadi pusat peradaban di zamannya. Minimnya investasi pemerintah dalam sektor infrastruktur dan industri menimbulkan angka pengangguran yang tinggi. Fenomena ini menyebabkan masyarakat Timur Tengah sulit untuk mendapatkan 
pekerjaan. Angka penganggguran menyebabkan timbulnya masalah kemiskinan yang menjadi pemicu berbagai masalah sosial lainya. Dari data Bank Dunia masyarakat Timur tengah menunjukkan angka pendapatan dengan rata-rata $2 \$$ per hari (The World Bank, 2017). Sehingga perputaran ekonomi pun melemah akibat daya beli yang kurang karena penduduk didominasi oleh kelas menengah ke bawah. Dengan beragam masalah yang timbul menyebabkan kawasan ini sangat dinamis baik secara politik maupun dari segi ekonomi. Sehingga menjadikan Timur Tengah sebuah kawasan yang rentan terhadap konflik.

\section{Nasionalisme Arab}

Di Eropa nasionalisme merupakan unsur penyebab pecahnya Revolusi Perancis. Di Timur Tengah nasionalisme adalah ideologi imaginatif yang sebenarnya tidak lahir dari Bangsa Arab. Nasionalisme Arab pertama kali di pelopori oleh dua orang pemikir. Yaitu Butrus alBustani, tokoh Lebanon yang beragama kristen katolik dan Nasif Elyazici yang berasal dari Yunani Katolik (Abu-Manneh, 1980). Al-Bustani merupakan pelopor dalam pembentukan indentitas bangsa Suriah dengan penduduk yang heterogen dengan berbagai latar belakang agama dan suku etnik (Abu-Manneh, 1980).
Pada abad ke 19. Banyaknya sekolah misionaris Kristen dan katolik di Timur Tengah seperti Amerikan Kolej di Beirut, Robert Kolej di Istanbul memicu menyebarnya ideologi barat. Sekolah misionaris ini mengajari berbagai ideologi barat seperti; republik, nasionalisme, demokrasi. Hal ini telah mendorong praktek politik bagi suku Arab yang beragama Kristen pada masa itu. Pada dasarnya Nasionalisme ini muncul untuk melawan kekuasaan Turki Usmani yang berkuasa di wilayah ini pada masa abad ke 19. Sehingga nasionalisme Arab dimunculkan untuk melawan kekuasaan Turki Usmani yang bercorak islam. Oleh sebab itu nasionalisme arab merupakan sebuah ideologi barat yang dipelopori oleh tokoh nonmuslim untuk memetik kekuasaan dari keruntuhan Turki Usmani.

Hingga saat ini tidak terdapat nasionalisme Arab yang solid, karena masyarakat arab sendiripun mengalami konflik terutama antara Sunni dan Syiah. Oleh sebab itu nasionalisme Arab bukanlah setimen yang dibangun untuk nasionalisme arab melainkan fanatisme agama yang menjadi unsur pemersatu dan pemecah grup etnik yang ada di wilayah ini. Bisa disimpulkan bahwa ideologi nasionalisme yang ada di Timur Tengah merupakan sebuah produk pemikiran barat yang perkenalkan 
melalui sekolah misionaris Eropa. Masyarakat Arab sendiripun tidak menerima nasionalisme model nationstate sebagai identitas kenegaraan. Sehingga sulit untuk masyarakat Arab untuk bersatu, belum lagi ditambah dengan latar belakang agama dan suku etnis yang berbeda.

\section{"ArabSpring": Benturan Ideologi Barat dan Intervensi Timur Tengah}

Banyak yang berpendapat bahwa "Arab spring/awakening" adalah awal mula wilayah Timur Tengah mengalami enlightenment. Masyarakat Arab berbondong-bondong turun ke jalan untuk memperjuangkan demokrasi, bak asasi manusia dan kehidupan yang layak dari pemerintahnya. Di berbagai mediadan bahkan menjadi buku banyak tulisan yang berargumantasi bahwa Arab Spring merupakan dinamika yang ditimbulkan oleh masyarakat Arab yang sadar akan hak-haknya sebagai warganegara. Gejolak Arab spring juga dipercepat dengan adanya media sosial. Jika dikaitkan dengan argumentasi penulis sebelumnya semua ini terjadi karena kegagalan sistem politik dan sistem ekonomi yang telah dibahaskan penulis sebelumnya. Yaitu masalah sosial seperti urbanisasi, peningkatan populasi, pengangguran dan kemiskinan sehingga menjadi pemicu demonstrasi yang dimulai dari Tunisia hingga ke Yaman. Kegagalan nilai ideologi barat baik dalam sistem ekonomi maupun rejim pemerintah menyebabkan terjadinya berbagai perpecahan yang bisa menjadi ancaman bagi perdamaian global. Ideologi barat berupa nation-state, nasionalisme, ekonomic liberalization menjadi bahan utama penguasa di Timur Tengah dalam membangun pemerintahan yang otokratik. Sehingga Arab Spring merupakan gambaran dari kegagalan rejim dan sistem ekonomi.

Sebagai contoh, Konflik di Libya salah satu progres yang menarik saat terjadinya penggulingan Muammar Kaddafi yang juga kerap dikenal sebagai "revolusi NATO" pada tahun 2011 yang silam. Pertikaian basar di Libya pada dasarnya adalah pertikaian antara kabilah. Yaitu pertikaian antar kabilah/suku yang ada di Bengazi dan Trablusgarp dalam memperebutkan sumberdaya alam Libya. Akan tetapi pertikaian ini mengundang negara ekskolonial Perancis ikut serta dalam penegakan "demokrasi" yang diinginkan oleh "masyarakat Libya". Masuknya Perancis dalam pertikaian yang terjadi di Libya juga mengundang NATO untuk ikut serta dalam memerangi Kaddafi yang dianggap sebagai diktator. Pada dasarnya secara ekonomi, Perancis juga memiliki kepentingan di Libya. Di mana salah satu ladang minyak terbesar di Libya 
dikelola oleh perusahan asal Prancis yaitu Total (Total, 2018). Sehingga pada ahirnya pemerintahan Kaddafi dijatuhkan dengan intervensi pihak asing melalui tangan masyarakat Libya sendiri.

Ini merupakan salah satu akhir dari "Arab Awekening" yang dibanggakan oleh media barat pada umumnya. Menurut penulis apa yang terjadi di Libya adalah pertikaian ideologi barat dan timur. Kaddafi yang menjunjung tinggi nilai sosialis dan menguasai sumber besar energi minyak di dunia tidak memberikan kesempatan bagi para pro barat. Barat sangat tidak senang ketika sumber perputaran roda ekonomi kapaitalis berada di tangan rejim diktator sosialis. Barat menggunakan nilai ideology demokrasi untuk menghancurkan Kaddafi dengan menggunakan rakyatnya sendiri. Sehingga apa yang terjadi di Libya bukanlah suatu hal yang alami melainkan sebuah ideologi global untuk melawan Kaddafi. Media sebagai ujung tombak dalam misi menjatuhkan rejim Kaddafi Libya, dengan segala upayanya memberikan penjelasan kepada masyarakat dunia bahwa rejim Libya adalah antidemokrasi. Sehingga intervensi NATO terhadap Libya secara militer diawali dengan perselisihan ideologi barat yaitu demokrasi yang tidak berhasil menggulingkan pemerintahan Kaddafi.
Apakah Libya membaik pasca Kaddafi? Apakah benar masyarakat Libya memperjuangkan "demokrasi"? Apa yang dikehendaki barat dan koalisinya? Ini semua menjadi pertanyaan yang harus dicerna kembali. Di mana Libya pasca rejim Kaddafi menjadi terbelah antara Benggazi dan Trablusgarpdikarenakan kompetisi kekuasaan antara dua kabilah. Etnik yang terbelah di Libya tidaklah memperjuangkan nilai demokrasi, melainkan memperebutkan sumber daya alam minyak. Negara barat seperti Inggris, Prancis dan AS tidak mungkin ikut mengintervensi Libya jika tidak memiliki kepentingan baik secara ideologis maupun ekonomi. Sumber energi minyak di Libya di operasikan dan hasilnya dibeli oleh perusahaan Inggris dan Perancis semenjak Rejim Kaddafi. Perusahaan ini seperti Shell Group, British Perol dan Total. Intervensi barat terhadap Libya bisa diterjemahkan sebagai pengamanan Aset barat yang berada di Libya. Ini adalah faktor sistem ekonomi liberal yang kejam hingga dengan harus memecah belah Libya untuk kepentingan sistem kapitalisme global. Untuk melegitimasi apa yang terjadi di Libya, media barat memaparkan seakan-akan kesejahteraan rakyat Libya akan ada jika demokrasi bisa diterapkan di Libya. Akan tetapi ini merupakan ideologi negara hegemon yang 
memiliki hegemoni ideologi baik dalam berpolitik internasional. Sehingga ideologi merusak konsep bernegara masyarakat Timur Tengah. Perpecahan dan konflik pun tidak bisa dihindari dengan dalih demi "demokrasi" dan masa depan masyarakat Libya.

\section{KESIMPULAN}

Berbagai peristiwa yang telah terjadi di Timur Tengah seperti di Suriah, Libya, Iraq, Mesir dan bahkan Afganistan sangatlah jauh dari perjuangan demokrasi demi kesejahteraan masyarakatnya. Pemahaman ideologi telah memicu masyarakat Timur Tengah berbeda pendapat dalam berpolitik. Sehingga mendorong dalam konflik dan perang saudara. Perbedaan agama, rejim politik dan juga suku etnik adalah penyebab utama masyarakat Timur Tengah berada dalam konflik. Ideologi barat seperti demokrasi adalah ideologi yang sangat bertentangan dengan nilai dan kultur rejim yang ada di Timur Tengah. Di mana masyarakat Timur Tengah lebih cenderung nyaman dengan rejim otokratik atau bahkan diktator dalam ungkapan barat. Ideologi seperti demokrasi, liberalisme dan hak asasi manusia bukanlah jalan keluar untuk penyelesaian konflik di Timur Tengah sangat tidak sesuai dan berseberangan dengan nilai kultur dan budaya berpolitik.
Kendatipun demikian demokrasi merupakan rejim politik kerap diterapkan di berbagai negara. Akan tetapi rejim demokrasi sulit untuk diterapkan di negara yang ada di Timur Tengah. Timur Tengah merupakan sebuah kawasan yang sangat dinamis dengan komposisi penduduk yang heterogen dari berbagai etnis, agama dan kultur. Penulis menyimpulkan bahwa demokrasi di Timur Tengah hanyalah ideologi yang digunakan oleh sebagian kelompok pro-barat untuk legitimasi publik dalam meraih kekuasaan. Hal ini telah dibuktikan dengan apa yang telah terjadi sepertidi Mesir, Suriah, Libya, Irak dan bahkan Afganistan. Sehingga rejim demokrasi bukanlah solusi bagi konflik yang muncul di Timur Tengah hingga sekarang. Dalam hal ini penulis memberikan rekomendasi bahwa baiknya sistem pihak asing tidak ikut intervensi dalam rejim politik yang ada di Timur Tengah. Karena masyarakat Timur Tengah memiliki budaya berpolitik tersendiri yang jauh dari pembahasan demokrasi, pun tujuan akhir yang dicapai adalah kesejahteraan rakyat. Oleh sebab itu membiarkan Timur Tengah tumbuh dengan sedirinya tanpa intervensi pihak asing baik secara ideologi maupunintervensi militer merupakan jalan keluar terbaik. Hal ini telah dibuktikan bagaimana keberhasilan rejim politik yang ada di negara teluk seperti Qatar, Arab Saudi 
dan Emirat Arab yang jauh dari pemikiran demokrasi. Bahkan Timur Tengah telah menjadi pusat perdaban terdahulu yang megah seperti Babilonia kuno hingga kerajaan Persia dan bertahan hingga berabad-abad.

\section{REFERENSI}

Abu-Manneh, B. (1980) "The Christians between Ottomanism and Syrian Nationalism: The Ideas of Butrus AlBustani", International Journal of Middle East Studies, Vol. 11, pp. 287-304.

Akdemir, S. (2000) 'Suriye'deki Etnik ve Dini Siyasi Yapının Oluşmasındaki Rolü/Peranan Struktur Politik Etnik dan Agama di Suriah", Avrasya Dosyasi, Vol. 6, pp. 201-237.

Atay, M. (2000) "Arab Baas Sosyalist Partisi Üzerine (Partai Sosialis Arab Ba'ath)", Avrasya Dosyası, Vol. 6(No. 1), pp. 131-154.

Chelkowski, Peter J. \& Pranger, Robert J (Eds). (1988) Ideology and Power in the Middle East, London: Duke University Press.

Gerald, B. H., \& Alasdair, D. (1985) The Middle East and North Africa: A Political Geography. The Middle East and North Africa, Oxford: Oxford University Press.

Koppes, C. R. (1976) "Captain Mahan, General Gordon, and the origins of the term 'Middle East', Middle Eastern Studies, Vol. 12.

Ottaway, M., \& Carithers, T. (2004) "Middle East Democracy", Foreign Policy, Vol. 145.

Shea, J. J. (2003) "The Middle Paleolithic of the East Mediterranean Levant", Journal of World Prehistory, Vol. 17, No. 4, pp. 313-394.
Shoup, J. A. (2011) Ethnic Group of Africa and Middle East. Santa Barbara, California: ABC-CLIO, LLC.

SIPRI. (2017) World Military Spending 2017

(Online). Tersedia di: http://visuals.sipri.org (Diakses: 28 Agustus 2018).

The World Bank. (2017) Wage and Salaried Workers, Male (\% of Male Employment) (Modeled ILO Estimate) (Online).

Tersedia di:

https://data.worldbank.org/indicator /SL.EMP.WORK.MA.ZS?locations= EG\&view=chart (Diakses: 27 Agustus 2018).

Total. (2018) Total in Libya (Online).Tersedia di: https://www.total.com/en/libya (Diakses 29 Agustus 2018).

Wikipedia (2018) Religion in the Middle East (Online). Tersedia di: https://en.wikipedia.org/wiki/Religio n_in_the_Middle_East (Diakses 28 Agustus 2018).

Wikipedia. (2018) Ethnic groups in the Middle East (Online). Tersedia di: https://en.wikipedia.org/wiki/Ethnic _groups_in_the_Middle_East (Diakses 28 Agustus 2018).

Wikipedia. (2018). Demographics of Egypt (Online). Tersedia di: https://en.wikipedia.org/wiki/Demo graphics_of_Egypt\#Ethnic_groups (Diakses 28 Agustus 2018).

World Bank. (2017) Military Expenditure (Online). Tersedia di: https://data.worldbank.org/indicator /MS.MIL.XPND.GD.ZS (Diakses 28 Agustus 2018). 